To cite this article: Liyanage, N, N, Medis,A.P. and Karunarathne, W.V.A.D. (2021). EVOLUTION OF MARKETING METHODS TOWARDS THE OMNI CHANNEL MARKETING -UNDERSTANDING THE JOURNEY THROUGH A LITERATURE REVIEW, International Journal of Research in Commerce and Management Studies (IJRCMS) 4 (5): 171-184

\title{
EVOLUTION OF MARKETING METHODS TOWARDS THE OMNI CHANNEL MARKETING -UNDERSTANDING THE JOURNEY THROUGH A LITERATURE REVIEW
}

\author{
Liyanage, N, $\mathbf{N}^{1}$, Medis, A.P² and Karunarathne, W.V.A.D. ${ }^{3}$ \\ ${ }^{1}$ Doctoral Candidate Faculty of Graduate Studies \\ University of Kelaniya Sri Lanka \\ +94772928645 \\ ${ }^{2}$ Senior Lecturer Department of Marketing Management \\ Faculty of Commerce and Management Studies \\ University of Kelaniya Sri Lanka \\ $+94777517715$ \\ ${ }^{3}$ Senior Lecturer Department of Accountancy \\ Faculty of Commerce and Management Studies \\ University of Kelaniya Sri Lanka \\ $+94777746462$
}

DOI: http://dx.doi.org/10.38193/IJRCMS.2021.3512

\begin{abstract}
Appreciating the massive evolvement of internet-based technology which has made massive changes to marketing methods globally, the purpose of this study is to identify the impact of omnichannel marketing on generating the revisit intention on the fashion store brands in Sri Lanka.
\end{abstract}

Within marketing management jargon, consumer revisit intention (RI) was being studied widely and it has proved that retaining customers is more advantageous than attracting new, because it would require less marketing resources to retain customers than inviting new ones.

As the marketing methods have aged, changed, evolved so is the consumer's thinking, expectations behaviour, and intentions. From radio to newspapers, television to social media, marketing has transformed with the mediums over the past several decades. Particularly social media which is the most recent development has changed marketing in several different ways. Social Media has completely transformed the consumer's lifestyles including how they interact with business organizations. Nowadays customers expect proactive service, personalized interactions, and connected experience. Therefore, various integrated marketing methods came to practice and latest of them being omnichannel marketing. in omnichannel marketing it suggests the integration of all 
physical channels (offline) and digital channels (online) to offer a unified customer experience.

In this paper, the literature related to the evolution of the marketing communications used by the practitioners from early dates to today will be analyzed and discussed to identify the attributes, features of different marketing communication methods used in different eras and theories and consumer behaviour and expectations that developed and shifted together with the development of the marketing communication.

KEYWORDS: Brand experience, Facebook Fan page, In-store marketing, Omnichannel Marketing, Revisit Intention

\section{INTRODUCTION}

The discipline of marketing and communication has changed and evolved in terms of its focus, practice and approach throughout the history together with the real world and lifestyles. The communication is the key that supports and facilitates the relationship of business organisation and consumer. Sellers communicate with the consumers about the use and features of their product or brand using words, signs, pictures and symbols to encourage them to purchase (Sharma \& Verma, 2018).

In this paper the literature related to the evolution of the marketing communications used by the practitioners from early dates to today will be analysed and discussed to identify the attributes, features of different marketing communication methods used in different eras and theories and consumer behaviour and expectations that developed and shifted together with the development of the marketing communication.

\section{The Early days}

In the early days it was believed that the foundational construct of marketing as exchange (Kotler \& Levi, 1969 as cited by Sheth \& Uslay, 2007). This exchange paradigm was explained by Seth \& Uslay (2007) referring the literature and it says the marketing exchanges are bringing benefit to at least three actors indirectly and among those three one exchanges is direct which makes it a complex in nature (Babozzi 1975 as cited by Seth \& Uslay, 2007). They further explain that those exchanges are mostly economic and intangible. Then this concept of exchanged evolved to a phase that the end result of the exchange should be satisfaction (Houston, Gassenheimer \& Maskulka, 1992). Together with this paradigm shift the focus of the business has shifted from product centric or segment centric to consumer centric and relationship driven (Sheth, Sisoida \& Sharma, 2010; Kumar, Umashankar \& Park, 2014). Prahalad \& Ramaswamy, 2004 explained the value creation process as it was created by the business organisation (Prahalad \& Ramaswamy, 2004).

The above-mentioned paradigm shifts occurred in par with the revolutions of media communication 
and according to Mark, Donald \& Shoesmith (2009), there were four revolutions that occurred in the media history as of now. The first is the birth of Greek alphabet which made people to communicate in written form, then the innovation of press, third is the mass media which is mostly TV and radio and finally the computers and social media (Mark, Donald \& Shoesmith, 2009). The marketing activities and involvements of the mode of communication varying from print, graphic, audio or visual influences the changes in consumer behaviour (Marcus, Owen, Forsyth, Cavil \& Fridinger, 1998).

\section{The Era of Mass- Media}

When searching the history of marketing communication, the literature goes back to 1960's to the era of mass-media which is the third revolution of media communication as per Mark et al., (2009). Undoubtedly the mass media which has driven the marketing communication to a new attractive and innovative direction. Mass media refers to the mediums that reaches to a large number of people at once such as television, radio, newspaper, magazines, books and billboards and it broadcasts messages throughout the society. Berelson \& Steiner (1964), have first defined the word "massiveness of media" as the ability to deliver a message from a single channel/ source to a large crowd (Berelson \& Steiner, 1964). Therefore, the actors of mass media are the single communicator and many receivers through a particular channel. The use of mass media was then got described as "used for the communication from a single source to a large number of points or form a single source to an audience that includes many people" (Grossberg, Wartella \& Whitney, 1998, p.8).

Advertising through mass media was proven to have several advantages and one of the main is it aggregate a large audience and deliver message to them (Mulhern, 2009). It is generally exposed to a very large audience hence, it has proven its ability on building brands (Hongcharu \& Eiamkanchanalai, 2009). The findings of Marcus et al., (1998) also confirms that the consumers have the ability to recall the messages delivered through mass media (Marcus et al., 1998).

The most famous marketing theories which is marketing mix consisting the 4p's and 7p's also introduced in par with the reformation of mass media marketing. The 4p's were on the main purpose of marketing practitioners in 1960's and it developed in to 7p's in the latter part of 1990's (Shultz \& Shultz, 1998). Although the main 4p's stands for product, price, promotion and place in the original 4p's marketing mix had 12 elements, product planning; pricing; branding; channels of distribution; personal selling; advertising; promotions; packaging; display; servicing; physical handling; and fact finding and analysis (Goi, 2009). The marketing mix alters and differs with consumer behavioural and social changes (Luca, 2010). Goi, 1970 explains the elements of 4p's as when it comes to product, it's about the quality of the product, variety, design, features, packaging, sizes and etc. Similarly, the price is about the list price, the discounts, allowances, credit period and terms. The promotion includes sales promotion, advertising, sales force, public relations and direct marketing when place considers on channels, coverage, assortments, locations, inventory and transform (Goi, 1970). Different scholars 
have provided different viewpoints to the marketing mix. Some argues it could be divided to two main categories as offerings (products related) and method and tools (sales and distribution related) while some argued it should be a mix of goods, services and distribution mix (Goi, 2009). In 1980's another three p's got added which are people/ participants, physical evidence and process which made it a 7p's in marketing (Goi, 2009). Kotler (1986) argued that political power and public opinion generation process to this mix.

\section{The Era of Internet}

In the 1970's and 1980's when internet was introduced it was mainly used by the technical audience of government agencies, academic researchers and scientists (Turban, Sharda, Aronson, Delen, Liang \& King,2007). When the communication methods have taken a new turn with the evolution of internet which is called as web 1.0 where consumers from around the world could interact with firms and each other through the multimedia platform called the worldwide web (Berthon, Pitt, Pangger \& Shapiro, 2012) the marketing practitioners also started finding their ways of communicating with consumers through internet. The academic literature on internet starts from early 1990's and they were mostly examined the technological aspects of the internet, user adoption to technology, vendor attributes and web site designs (Taylor \& Struttorn,2010).

The academic literature on internet marketing has started from mid-1990's, Hoffman \& Nawak (1996) introduced a model named hypermedia computer mediated communication model and they argue that the hypermedia provides better control over consumer control, accessibility, flexibility and sense stimulation. At early days of 1990's the promotional or advertising activities that took place via internet was non-graphical but a simple text messages mostly through electronic mails, and the IT based business organisations has used it to update theory product information to the consumers (Poon \& Jevons, 1997). Alba \& Lynch (1997) suggested the consumer psychology of incentives to go online. In the early studies on internet marketing has suggests that the information search process, purchase outcomes and satisfactions were supported by the interactive decision aids facilitated through the internet as a result of evolving to patterns distinctly different from the brick-and-mortar store environments (Lee \& Geistfeld,1998; Hollander \& Rassuli, 1999; Haubl \& Trifts, 2000; Bechwati \& Xia, 2003). When marketing through online has started the marketplace become interactive and no longer limited to one-way communications from sellers to buyers. Technology has facilitated the consumers to share their thoughts, opinion and expectations through discussions, ratings, reviews and blogs which is visible to the marketplace and this leads to consumers to communicate with one another which was an unusual development in the marketplace (Moe \& Schweidel, 2012). The information technology has expanded the toolkit of marketing communication for creation, execution and delivering the marketing communication programme which resulted to change the entire marketplace (Shultz \& Shultz, 1998). Although internet provided the opportunity to direct marketing, the strategies such as hard selling and push promotions has not being very successful (Poon \& Jevons, 1997). 
Anyhow, the internet marketing has created the price competition among sellers, the reason is that since the availability of price information has made the web using consumers price sensitive and this has made the intellectual property to be available for a very low unstable price (Poon \& Jevons, 1997). A major problem that web buyers of that age faced was the trust and payment methods. Although the buying and selling has advanced to be web based the payment methods were still traditional such as sending the credit card details to the seller (Poon \& Jevons, 1997). The success of web-based business has lied behind the adaptation to the changes and continuous interaction (O'Keefe, O'Cornnor \& Kung, 1998). The academic researchers have identified that there is a need of a paradigm shift on internet-based selling to improve to reach towards international selling and it should minimize the problems that it had (Poon \& Swatman, 1995).

The argument on TAM (Technology Acceptance Model) about using internet for marketing is, when all else are constant, consumers choose a system that offers them the highest benefits to perform a task and easiest to use (Taylor \& Strutton, 2010). The studies have found out that the perceived value provided through internet when shopping is high as it saves time, can get delivered to home, lower prices and increase of availability (Parasuraman \& Grewal, 2000). With understanding the different variables such as trust, entertainment, intrinsic and extrinsic motivations, the TAM has continuously re-developed and tested and applied by different scholars (King and He, 2006; Schepers and Wetzels, 2007).

\section{The Era of social media}

The World Wide Web, started to trigger since 2004, which then started referring as web 2.0 that has accelerated altering the landscapes of media, communication, business and daily lives (Macnamara, 2010). Web 2.0, when the social network ( $\mathrm{SN}$ ) sites were introduced the business organisations also started to communicate with their consumers through social SN sites. This was called as social media marketing (SMM). It was defined by Akar \& Topu (2011) as "use of social media channels to promote a company and its products" (Akar \& Topu, 2011). According to Berthon et al. (2012), the web 2.0 came along with three major changes namely, the activities changed from desktop to the web, the value creation from firm to the consumer and finally the power from firm to consumer. The major transformation came along with Web 2.0 is the change of focus from companies to consumers where consumers get personal attention and individuals to communities where communities could be gathered through fan pages (Berthon et al. 2012). Although Web 2.0 is a technological transformation its major effect is sociological which had effects on business communication. With the added element of real time interactivity Web 2.0 has got rid of some elements such as time and geography (Sharma \& Verma, 2018). SMM has opened the doors to two-way communication with brands and helped to enhance the brand value by reducing the consumer prejudice (Kim \& Ko, 2012). The attributes of web 2.0 was being widely discussed by scholars as an interactivity and collective intelligence via two-way communication (O' Reilly, 2005), as an attitude (MacManu, 2005) also as a culture which has less of 
control over but more united (Jenkins, 2006). Kempe, Kleinberg \& Tardos, (2003) defines social media as a graph of relationships and interactions within a group of individuals, often mediating and spreading information, ideas and influence among members. The facility of online interactions which acts as word of mouth too (Kempe, Kleinberg \& Tardos, 2003).

Social media has enabled the freedom to express personal information. The social media users are enjoying the exceptional/ unconventional methods to document and communicate activities, opinions and thoughts of their daily life through social media platforms. This behaviour has made it all possible to collect and analyse the content for commercial and business purposes (Geru et. al 2008). It was identified that the organisations could gain a competitive advantage when they use the information shared by users to understand their behaviour and apply that knowledge to market through social media targeting the desired audience. The special features that social media offers such as value cocreation, EWOM (Electronic word of mouth), AI (Artificial Intelligence) has made the social media platforms a revolutionary marketing tool.

One of the key features of social media is user-generated content, which facilitates the concept of value co-creation. About a decade ago the value creation was organisation centric with the emerging trends in marketing strategies the value creation has taken a new leap as value co-creation. This has converted the isolated consumer to be connected. Value- co-creation begins when the business organisation and the consumer create value together by interacting with each other (Prahalad \& Ramaswamy, 2004). Social media provides the opportunity to 'hit like', 'comment' and 'share the post' which are the mechanisms of value co-creation. Besides the social media sites facilitates the consumers to interact with each other, share their experience and receive an opinion from others. These features enhance the value of co-creation.

Another key feature of social media marketing is the electronic word of mouth (EWOM). Henning \& Thurau (2004) has defined as "EWOM is any positive or negative statement made by potential, actual or former customer about a product or a company, available to a multitude of people and institutions via the internet" (Henning \& Thurau, 2004). The credibility of EWOM can be measured if the consumer recognises the product information, reviews and recommendations as truthful (Cheung, Luo, Sia \& Chen, 2009).

Artificial Intelligence (AI) is today's one of the most remarkable research fields and it can be used easily to intelligent content marketing (Kose \& Selcuk 2017). Through this, the consumers will be automatically notified about the products and brands of their choice. The content can be created after identifying consumer behaviour (Geru, Micu, Capatina \& Micu, 2018).

When business organisations started using social media for marketing purposes scholars has 
introduced few new theories related to the social media marketing, namely viral marketing, information adoption, social presence, media richness and social networking theories.

Viral Marketing serves as the electronic or mobile word of mouth (Polka, Pousttchi \& Wiedemann, 2009). It is a known fact that word of mouth marketing influences the purchase decisions. Moore (2003) defined viral marketing as "the name applied to a group of family resembling marketing strategies using network enhanced word of mouth" (Moore, 2003).

Viral marketing spreads out so fast as a virus and takes advantage of multiplication to transmit the message to thousands and millions in a very short period of time. The main advantage is that it provides high and rapid response rate to a very low cost. Viral Marketing is successful when there is a demand for the information/ content, the positive intension to share the experience and ideas of products or services and the customer to customer (C2C) electronic communication capability is met (Rindings, Gefen \& Arinze, 2002). The success of viral marketing lies on awareness, interest, access to use marketing techniques and the experience that influences the decision (Arnaud \& Lilien, 2008).

Viral Marketing (VM) or Electronic Word of Mouth (EWOM) explains how the basic information transfers from person to person and Information adoption theory (IAT) extends that knowledge in the ways how the content of basic information may differ as it spreads (Chaiken \& Eagly, 1976). The study of Sussaman \& Siegal (2003) found that IAT explains how people may change the information and accordingly how they change their intensions and behaviours in online platforms (Sussman \& Siegal, 2003). Christy et al., (2008) has found that the factors affecting online information adaptation has four dimensions on quality and two dimensions of source credibility. Relevancy, timeliness, accuracy and comprehensiveness are the four main pillars in quality and source expertise and trustworthiness comes under source credibility (Cheung, Lee \& Rabjohn, 2008). On their paper Gunawan and Huarng (2015) has demonstrated the importance of information adaptation model and social integration with prior use of Theory of Research Action (TRA) and discussed motivational factors in consumer's intension to purchase virally marketed product via social media network. Their findings have proved that the source credibility and social influence heavily impacts on customer purchase intension in social media marketing (Gunawang \& Huarng, 2015).

Social presence theory was defined as the ability of a communications medium to transmit social signals (Short, Williams \& Christie, 1976). The social presence factors are identified as having a positive effect on building trust in sellers (Baozhou, Weiguo \& Mi, 2016). Its characteristics can be described as multi-dimensional and flexible. It identifies the interests of target audience and creates a personal connection between them (Kathy, Angela \& Mohamed, 2009). It measures the psychology of the individual on their social orientation and through that it identifies the motivational and thinking patterns (Kathy et al., 2009). 
Chang and Hsu (2016), has identified that the recipients understanding of the message is influenced by the medium influences and this motivates the receiver to participate in social interactions (Chang $\&$ Hsu, 2016). The findings of Frimpomg and McLean (2017) suggests that social presence offer a basis for the practices of social brand engagement.

The media richness theory is an information processing discuss about the ability of one communication method to reproduce the same information. When face to face communication takes place, one can explain the same content using words, gestures, voice variations, facial expressions and also by using pen and paper to draw charts and figures (Dennis \& Kinney, 1998). According to the findings by Hopkins 2012 the Facebook business page provides an interactive social media customer communication tool with multiple communication capabilities such as customer to customer, business to customer and customer to business (Hopkins, 2012).

The role of social relationships on communicating or transmitting the information, and the ways of which the media could enable the attitudinal and behavioural changes is being defined by the Social Network Theory (Rossler, Hoffner \& Zoonen, 2017). The properties of social networks are transitivity, density and closure (Richardson, Peggy \& Mark, 2016),

Scholars has researched the impact of social media marketing on the businesses over last decade and found positive impact. Richardson et al., (2016) suggests that if the corporate networks to social media sites were carefully integrated as Facebook firms can achieve their marketing communication goals well.

With the development of smart mobile, the marketing methods have started to intergrade with mobile marketing too. According to the findings of Heinonen \& Strandvik (2003), mobile channels are more personal than traditional marketing methods and emails (Heinonen \& Strandvik, 2003). It is certain that the attachment between consumers and the mobile device is highly strong (Wilska, 2003).

When consumers get familiar with these various communication technologies, they choose different times and different channels to interact with the business organisations and on the decision-making process (Ragaswamy \& Van Brugen, 2005). Therefore, the concept of integrated marketing communication (IMC) emerged in 20th century to help the business organisations to utilize these consumer touch points and various communication channels for the better use. Duncan \& Everett (1993) listed the reasons for the birth of IMC referring literature as acquisitions and mergers of communication agencies, the complexity level of clients and retailers, the high cost of traditional marketing modes and weaknesses of them, the growing competition, technology advancement etc (Duncan \& Everett, 1993). The IMC was defined as "the process of strategically developing and 
controlling or influencing all messages used to build and nourish relationships with the customers and other stakeholders" (Duncan \& Everett, 1993; p3). The purpose of IMC is to help the organizations to create coordinated and consistent messages across the different various channels (Kitchen \& Burgmann, 2010). It builds strategic relationships with the stakeholders which leads to customer loyalty (Kitchen \& Burgmann, 2010). The Kilatchko (2005) has understood IMC as "a concept and process of strategically managing audience- focused, channel centred and result driven brand communication programmes over time" (Kilatchko, 2005; p 21). The central idea of IMC is to integrate different communication disciplines through integrating contact points and the message to obtain a better outcome (Kitchen \& Burgmann, 2010). The integration of message helps the consumer to obtain only what they need, and it helps them to not to get confused with several information from various different channels (Stewart 1996 as cited by Kitchen \& Burgmann, 2010).

Ragaswamy \& Van Brugen (2005), have explained this as they search information from websites and purchase offline, and they referred customers who use more than one channel to interact with business organisations as multi-channel customers and the marketing methods to reach multi-channel customers as multi-channel marketing. Neslin, Grewal, Leghorn, Shankar, Teering, Thomas \& Verhof (2006) has suggested that the customers are more prone to use more than one channel during their shopping process on different stages of search, purchase and post purchase activities. Multichannel marketing has begun combining the web applications and wireless devices for marketing purposes (Valos, 2008). Ragaswamy \& Van Brugen (2005) further explains that multichannel marketing creates strong customer relationships through offering their customers the information related to products, services and support via two or more synchronized channels. Multichannel marketing is challenging and complex as it involves a number of components, processes and decisions for the business organisations with related to the customers, internal structures, channels, organisational culture and communication (Weinberg, Parise \& Guinan, 2007; Valos, 2009). The definition of Neslin et al. (2006) on multichannel marketing is 'the set of activities that encompasses the design, the deployment, coordination, and evolution of channels to enhance customer value through effective customer acquisition, retention and deployment' (p.96). During the period of $2000-2005$, the scholars has identified that multichannel consumers are rising (McKey, 2004; Gaffney,2005). Also, the benefits of using multichannel marketing was identified as, multichannel shoppers tend to spend more (Myers, Pickersgill \& Van Metre, 2004; Kumar \& Venkatasan, 2005), buys more products (Kumar \& Venkatasan, 2005), and it improves the profitability (Berger, Lee \& Weinberg, 2006).

The practical problems arose on multichannel marketing was explained by Mirsch, Lehrer \& Jung (2016), is that the failure of interconnecting the channels, which is occurred when the channels are treated and managed separately. The example Mirsch et al. (2016) has given is that the retailers who has the website and a physical store offers the facility of ordering online, yet it doesn't support the return of the product because of the lack of channel integration. The main concern arose on multi- 
channel marketing was the silos of organizations such as organizational gratification and capabilities, organizational structure and culture, communication and technological assets which hinders the capability of making the message integration and coordinate the channels and prioritise them and finally it hinders the path to purchase (Payne, Peltier \& Barger, 2017).

\section{Central to the discussion of contact points}

and message integration is the idea of incorporating different communication disciplines into one marketing communication campaign with the aim of achieving outcomes desirable to the company, for example, persuading customers to buy. While the multichannel marketing gives its focus to the channel omnichannel marketing focuses on the interaction between the consumer and the brand by assuring maximum information availability, visibility and consistency across all the channels they use (Piotrowicz \& Cuthberston, 2014). The marketers use omnichannel to close the gap between online and offline marketing (Azhari \& Benette, 2015). One major aspect of omnichannel is the customization of the marketing communication from customer to customer depending on their personal preferences. Retailers could collect the customer related information through loyalty cards and through their online, social media activities and through artificial intelligence related to the products and adjust the offerings and communication catering to the individual preferences (Piotrowicz \& Cuthberston, 2014). Tyrväinen, Karjaluoto \& Heikki (2018), has defined the omnichannel concept as the use of many channels as internet and mobile devices together with the physical store within the same transaction (Tyrväinen, Karjaluoto \& Heikki, 2018). When comparing multichannel and omnichannel Verhoef et al. (2015) found that the omnichannel management is interactive, the channels are inclusion of the stores, online websites, direct marketing, mobile channels, social media, TV, radio, print and communication between $\mathrm{C} 2 \mathrm{C}$ and all these channels provides seamless retail experience (Verhoef et al., 2015).

Omnichannel makes the consumer to feel like that the difference of online and in-store shopping as very little (Adweek, 2013). The definition of Verhoef et al. (2015) on omnichannel is 'the synergetic management of the numerous available channels and customer touchpoints, in such a way that the customer experience across channels and the performance over channels is optimized' (p. 176). Omnichannel is aimed to provide a coordinated processes and technologies through all online and offline channels to provide seamless, consistent and reliable (Verhoef, Kannan \& Inman, 2015).

Saghiri, Wilding, Mena \& Bourlakis (2017) in their study on toward a three-dimensional framework on omnichannel has aimed to develop a conceptual framework for omni channel systems. They have recognized omnichannel as a complex adoptive system. With reference to the omnichannel framework they proposed, they have distinguished the omnichannel system in to three dimensions to maintain connectivity and interaction, which are channel stage, channel type and channel agent. Channel stage is the different stages of a transaction process, pre-purchase, purchase, payment, delivery and return. 
Channel type is the various different mediums that consumers refer on channel stages to refer information. Such as website, Facebook page, email, catalogue etc. Channel agent is whom that manage the channel type. It may vary from manufacturer, retailer, delivery agent or bank. The authors suggest that the integration among channel stages provides a smooth customer experience and it is a transparent process to both consumer and business organisation on all the stages of buying process. (Saghiri et al. 2017).

The challenges of omnichannel marketing and possible ways to overcome them was studied by Coupey, Hure \& Piveteau (2015) through an in-depth longitude case study on French online eye-wear store. They have first identified four key characteristics of omnichannel which it gets distinguished from other channel integration. The characteristics are omnichannel involves more channels, implies broader perspectives through customer touch points, disappears the differences between different channels and it provides a greater customer brand experience.

Lee \& Leonas (2018), have conducted their study on Consumer experiences, the key to survive in an omni-channel environment: use of virtual technology with the aim of identifying the mechanisms to successfully manage virtual technologies and to provide some implications to practitioners on the effective managerial approaches to be succeeded.

\section{CONCLUSION}

The purpose of this literature review is to understand the evolution, theories used in different eras and milestones of marketing from early days to date to understand the nature of marketing methods used in different eras. Finally, to analyse the impact of the new marketing method of omni channel marketing which utilizes the technology and communication methods to provide seamless communication to the customers.

\section{REFERENCES}

Adweek (2013) Marketing to the Omnichannel Shopper, Adweek, 54 (22), pp. 1-2.

Akar, E., \& Topcu, B. (2011). An Examination of the Factors Influencing Consumers' Attitudes Toward Social Media Marketing. Journal of Internet Commerce, 10, 35-67.

Alba, J., Lynch J. Interactive home shopping: consumer, retailer, and manufacturer incentives to participate in electronic marketplaces. J Mark 1997;61(3):38-53

Berelson, B., \& Steiner, G. A. (1964). Human behavior: An inventory of scientific findings. New York: Harcourt, Brace \& World. 
Vol. 3, Issue.5, Sep-Oct 2021, p no. 171-184

Cheung, C., Lee, M., \& Rabjohn, N. (2008). The impact of electronic word of mouth: The adoption of online opinions in online customer communities. Internet Research. 18 (3), 229-247.

Frimpong, K. O., \& McLean, G. (2018). Examining Online Social Brand Engagement: A Social Presence Theory Perspective. Technological Forecasting and Social Change. 128, 10-21.

Goi, C. L. (1970). Marketing Mix: A review of'P'. The Journal of Internet Banking and Commerce, 10(2), 1-11.

Goi,C.L. (2009). A Review of Marketing Mix: 4P's or More. International Journal of Marketing Studies, 1 (1), 2-15

Grossberg, L., Wartella, E., \& Whitney, D. C. (1998). Mediamaking: Mass media in a popular culture. Thousand Oaks, CA: Sage.

Hoffman DL, Novak TP. Marketing in hypermedia computer-mediated environments: conceptual foundations. J Mark 1996;60(3):50.

Hongcharu, B., \& Eiamkanchanalai, S., (2009). A comparative study of traditional mass media, the internet and mobile phones for integrated marketing communications. Journal of Business \& Economics Research, 7(12), 31-40

Houston, F. S., Gassenheimer, J. B., \& Maskulka, J. M. (1992). Marketing exchange transactions and relationships. Quorum Books.

Kempe, D., Kleinberg, J., \& Tardos, E. (2003). Maximizing the spread of influence through a social network Proceedings of the ninth ACM SIGKDD international conference on Knowledge discovery and data mining (pp. 137-146).

Kim, A. J., \& Ko, E. (2012). Do Social Media Marketing Activities Enhance Customer Equity? An Empirical Study of Luxury Fashion Brand. Journal of Business Research, 65(10), 1480-1486.

Kumar, V., Umashankar, N., Park, I. (2014). "Tracing the Evaluation \& Projecting the Future on Instore Marketing”. Shopper Marketing and the Role of on In-store Marketing, 11, 27-56.

Lee, G., \& Lin, H. (2005). Customer perceptions of e-service quality in online shopping. International Journal of retail and distribution management, 33(2), pp. 161-176. 
Vol. 3, Issue.5, Sep-Oct 2021, p no. 171-184

Lee, H. and Leonas, K, K. (2018). Consumer Experiences, The Key to Surviving in an Omnichannel Environment- Use of Virtual Technology, Journal of Textile and Apparel, Technology and Management, 10 (3), 1-23.

Lee, M. S., Hsiao, H. D. and Yang, M. F. (2011). The study of the relationships among experiential marketing, service quality, customer satisfaction and customer loyalty, The International Journal of Organizational Innovation, 3 (2), pp. 352-378.

Macnamara, J. (2008). Internet media and the public sphere: The 2007 Australian e- electioneering experience. Media International Australia, 129, 7-19.

Marcus, B., Owen, N., Forsyth, L., Cavill, N., \& Fridinger, F. (1998). Physical activity interventions using mass media, print media, and information technology. American journal of preventive medicine, 15(4), 362-378.

Mark, B., Hemelryk Donald, S., \& Shoesmith, B. (2009). Media Theories \& Approaches: A Global Perspective.

Moore, R. (2003). From genericide to viral marketing: on 'brand'. Language and Communication. 23, 331-357.

Mulhern. F., (2009) Integrated marketing communications: From media channels to digital connectivity, Journal of Marketing Communications, 15 (2-3), 85-101

O’Keefe, R. M., O’Connor, G., \& Kung, H. (1998). Early adopters of the Web as a retail medium: small company winners and losers. European Journal of Marketing, 32(7/8), 629-643. doi:10.1108/03090569810224038

O'Reilly, T. (2005, September 30). What is web 2.0: Design patterns and business models for the next generation of software. O'Reilly blog. Retrieved July 22, 2020, from http://www.oreillynet.com/pub/a/oreilly/tim/ne ws/2005/09/30/what-is-web-20.html

Piotrowicz, W., \& Cuthbertson, R. (2014) Introduction to the Special Issue Information Technology in Retail: Toward Omnichannel Retailing, International Journal of Electronic Commerce, 18:4, 516, DOI: $10.2753 / J E C 1086-4415180400$

Polka, W., Pousttchi, K., \& Wiedemann, D. (2009). Mobile word-of-mouth - A grounded theory of mobile viral marketing. Journal of Information Technology. 24, 172-185. 
Vol. 3, Issue.5, Sep-Oct 2021, p no. 171-184

Poon, S., \& Jevons, C. (1997). Internet-enabled international marketing: A small business network perspective. Journal of Marketing Management, 13(1-3), 29-41. doi:10.1080/0267257x.1997.9964457

Saghiri, S., Wilding, R., Mena, C., Bourlakis, M. (2017). Toward a three-dimensional framework for omni-channel. Journal of Business Research, 77, 53-67.

Schultz, D. E., \& Schultz, H. F. (1998). Transitioning marketing communication into the twenty-first century. Journal of Marketing Communications, 4(1), 9-26. doi:10.1080/135272698345852

Sharma, S., \& Verma, H, V. (2018). Social Media Marketing: Evolution and Change. Social Media Marketing, 19-36.

Sheth, J. N., Sisodia, R. S., \& Sharma, A. (2000). The Antecedents and Consequences of CustomerCentric Marketing. Journal of the Academy of Marketing Science, 28(1), 55-66.

Short, J., Williams, E., \& Christie, B. (1976). The social psychology of telecommunications. John Wiley \& Sons.

Taylor, D.G., Struttorn, D. (2010). Has e-marketing come of age? Modeling historical influences on post-adoption era Internet consumer behaviors. Journal of Business Research, 63 (9-10), 950-956.

Turban, E., Sharda, R., Delen, D., Aronson, J.E., Liang, Ting-Peng.,King, D. (2011). Decision support and business intelligence systems. Pearson Education India.

Verhoef, P.C., Kannan, P. K. and Inman, J. J. (2015). From multi-channel retailing to omnichannel retailing: introduction to the special issue on multi-channel retailing, Journal of Retailing, Vol. 91 No. 2, pp. 174-181.

Verhoef. P.C., Hoekstra. J.C., Aalst. M. (2000). "The effectiveness of direct responses radio commercials: Results of a field experiment in the Netherlands", European Journal of Marketing, Vol. 34, pp. 143-155. 